\title{
Stable coexistence in marine algal host-virus systems
}

\author{
Runar Thyrhaug ${ }^{1,2, *}$, Aud Larsen ${ }^{1}$, T. Frede Thingstad ${ }^{1}$, Gunnar Bratbak ${ }^{1}$ \\ ${ }^{1}$ Department of Microbiology, University of Bergen, Jahnebakken 5, Postbox 7800, 5020 Bergen, Norway \\ ${ }^{2}$ Present address: Nordland Research Institute, 8049 Bodø, Norway
}

\begin{abstract}
All microalgal host-virus systems isolated to date are lytic: the viruses lyse the infected hosts within hours after infection. Moreover, current models of phytoplankton host-virus interactions predict rapid extinction of both host and virus. Nevertheless, marine phytoplankton and their respective viruses do coexist in marine ecosystems. To investigate this apparent paradox we performed a series of experiments which show that phytoplankton populations always recover after virus-induced lysis and that endemic viral infections may promote survival of the host population. We hypothesize that phenotypic plasticity of algal susceptibility to viral infection makes such coexistence of host and virus possible.
\end{abstract}

KEY WORDS: Phytoplankton · Marine viruses · Coexistence $\cdot$ Viral ecology

\section{INTRODUCTION}

Viruses infecting, killing and lysing phytoplankton are ubiquitous in marine ecosystems. They are recognized as active members of marine plankton communities, and they influence many important biogeochemical and ecological processes (Fuhrman 1999, Suttle 2000, Wommack \& Colwell 2000). Several case studies have reported that viruses are involved in termination of algal blooms (Bratbak et al. 1993, 1995, Nagasaki et al. 1995, Nagasaki \& Yamaguchi 1997, Castberg et al. 2001), but they may also control algal populations by keeping them at non-blooming levels (Zingone et al. 1999, Larsen et al. 2001).

All phytoplankton host-virus systems isolated to date are lytic (Mayer \& Taylor 1979, van Etten \& Meints 1999, Sandaa et al. 2001) and current models, which are based on our present conception of these systems (Bratbak et al. 1998), suggest rapid extinction of both the alga and its virulent virus. However, Zingone et al. (1999) reported that both Micromonas pusilla and viruses infecting this phytoplankter could be found together in water samples collected from the Gulf of Naples (Mediterranean Sea) during all seasons. Similar observations were made by Tarutani et al. (2000) who reported that Heterosigma akashiwo persisted in Hiroshima Bay together with its virus. The explanation proposed by Tarutani et al. (2000) was that host and virus persisted due to clonal successions of specific host-virus systems. Although this may explain the persistence of a species over short time periods, extinction of host clones should still occur if the model is assumed to be also valid for clonal host-virus systems. The solution could be that virus-resistant clones, and corresponding host-range virus mutants (Waters \& Chan 1982), evolve and extinguish at high rates. However, severe mutational constraints makes such an 'arms race' between host defenses and counter-defenses of the parasite unlikely as an ecological regulating mechanism (Lenski 1984, Lenski \& Levin 1985).

The aim of this study was to examine the recovery of algal cultures following viral infection and to evaluate the ecological implications of this process. Viruses depend on available host organisms for reproduction implying that both viruses and algae share a common interest in avoiding host extinction. We demonstrate here that coexistence of algae and viruses is possible, and we attribute this to an efficient feedback mechanism that reduces the infection rate when the host abundance becomes low due to viral lysis. 


\section{MATERIALS AND METHODS}

Cultures. The algal species used in this study were Phaeocystis pouchetii (Hariot) Lagerheim (Prymnesiophyceae) strain AJ01, Pyramimonas orientalis McFadden, Hill \& Wetherby (Prasinophyceae) strain IFM, Chrysochromulina ericina Parke et Manton (Prymnesiophyceae) strain IFM and Emiliania huxleyi (Lohmann) Hay et Mohler (Prymnesiophyceae) strain BOF92 obtained from the culture collection at the Department of Fisheries and Marine Biology, University of Bergen, Norway. The respective viruses used were the Phaeocystis pouchetii virus PpV-01 (Jacobsen et al. 1996), Pyramimonas orientalis virus PoV-01B (Sandaa et al. 2001), Chrysochromulina ericina virus CeV-01B (Sandaa et al. 2001) and Emiliania huxleyi virus EhV-99B1 (Castberg et al. 2002). The algae were grown in $\mathrm{f} / 2-\mathrm{Si}$ medium (Guillard 1975), based on aged and autoclaved seawater (N:P ratio 24:1). Algal cultures were grown at a L:D cycle of $16: 8 \mathrm{~h}$ at $15^{\circ} \mathrm{C}$, except $P$. pouchetii which was grown at $8^{\circ} \mathrm{C}$. The light intensity applied was 40 to 50 (mol quanta $\mathrm{m}^{-2} \mathrm{~s}^{-1}$.

Regrowth experiments. Exponentially growing cultures $(100 \mathrm{ml})$ of each algal species were inoculated in triplicate with 4 different viral concentrations: $3 \times 10^{4}$, $3 \times 10^{5}, 3 \times 10^{6}$, and $10^{7} \mathrm{ml}^{-1}$ (final concentration). The host concentration was in all cases ca. $10^{5} \mathrm{ml}^{-1}$. Samples for enumeration of algae and viruses were collected at regular intervals for 4 to $7 \mathrm{wk}$.

To test the infectivity of the viruses, the hosts' resistance to viral infection, and if viral production continued in the recovered cultures, we infected fresh algal cultures and initiated test experiments when the cultures were in the recovery phase. For the infectivity test, we centrifuged $10 \mathrm{ml}$ of each algal culture for 10 min at $5000 \times g$ to remove most of the algae and debris, filtered the supernatants through $0.2 \mu \mathrm{m}$-pore size syringe filters (Schleicher \& Schuell) and added $5 \mathrm{ml}$ of the filtrates to $50 \mathrm{ml}$ of exponentially growing host cultures. Samples for enumeration of algae and viruses were collected every $2 \mathrm{~d}$ for $12 \mathrm{~d}$. The susceptibility of the recovered host algae to viral infection was tested by adding $10 \mathrm{ml}$ stock virus lysate to recovered cultures in exponential growth. Samples for enumeration of algae and viruses were collected every $2 \mathrm{~d}$ for $12 \mathrm{~d}$. To test if the recovered host algae continued to produce viruses, $10 \mathrm{ml}$ of recovered cultures in exponential growth phase were diluted in $90 \mathrm{ml}$ of fresh $\mathrm{f} / 2$ medium. Samples for enumeration of algae and viruses were collected at regular intervals for 20 to $22 \mathrm{~d}$.

Inhibition experiment. The possible effect of filterable cues (i.e. any molecule or particle that passes through a $0.02 \mu \mathrm{m}$ filter and inhibits viral production) on viral lysis was examined by adding virus-free lysate (VFL) to cultures prior to addition of the respective virus. Virus-free lysate was obtained by filtration of stock virus lysate (VL) through $0.02 \mu \mathrm{m}$ anodisc filters (Millipore). VL and VFL were added to exponentially growing algal cultures in duplicate as follows: (1) $10 \%$ $\mathrm{v} / \mathrm{v}$ VFL and, 10 min later, VL to a total viral concentration of $10^{7} \mathrm{ml}^{-1} ;$ (2) $10 \% \mathrm{v} / \mathrm{v}$ VFL and, 10 min later, VL to a total viral concentration of $10^{5} \mathrm{ml}^{-1}$; (3) VL to a total viral concentration of $10^{7} \mathrm{ml}^{-1}$ and $10 \% \mathrm{v} / \mathrm{v}$ fresh medium; (4) VL to a total viral concentration of $10^{5} \mathrm{ml}^{-1}$ and $10 \% \mathrm{v} / \mathrm{v}$ fresh medium. Samples for enumeration of algae and viruses were collected at regular intervals for 7 to $9 \mathrm{~d}$.

Long-term infection experiment. To investigate the long-term stability of the host-virus interaction in the

Table 1. Equations, parameters and initial values used to simulate Phaeocystis pouchetii, $\mathrm{PpV}$ and inhibitor concentration over the first $300 \mathrm{~d}$ after initiation of agal recovery following viral lysis (see Fig. 7). a.u.: arbitrary units

\begin{tabular}{|c|c|c|c|}
\hline \multicolumn{4}{|c|}{ Differential equation } \\
\hline \\
\hline \multicolumn{3}{|c|}{$\frac{\mathrm{d} A}{\mathrm{~d} t}=\mu A-\frac{S_{1}}{1+I} S_{2} \alpha V A$} & $A_{0}=1 \times 10^{3}$ cells ml ${ }^{-1}$ \\
\hline \multirow{2}{*}{\multicolumn{2}{|c|}{$\frac{\mathrm{d} V}{\mathrm{~d} t}=m \frac{S_{1}}{1+I(t-\tau)}$}} & \multicolumn{2}{|c|}{$S_{2} \alpha V(t-\tau) A(t-\tau)-\frac{S_{1}}{1+I} \alpha V A-\lambda_{V} V$} \\
\hline & & & $V_{0}=1 \times 10^{8} \mathrm{ml}^{-1}$ \\
\hline \multicolumn{4}{|c|}{$\frac{\mathrm{d} I}{\mathrm{~d} t}=k \frac{S_{1}}{1+I(t-\tau)} S_{2} \alpha V(t-\tau) A(t-\tau)-\lambda_{I} I \quad I_{0}=100$ a.u. } \\
\hline \multicolumn{4}{|c|}{ Parameters } \\
\hline Symbol & Values & Unit & Explanation \\
\hline$\mu$ & 0.015 & $\mathrm{~h}^{-1}$ & $\begin{array}{l}\text { Algal specific growth } \\
\text { rate }\end{array}$ \\
\hline$m$ & 400 & virus cell $^{-1}$ & $\begin{array}{l}\text { Virus released per } \\
\text { lytic event (burst } \\
\text { size) }\end{array}$ \\
\hline$\tau$ & 15 & $\mathrm{~h}$ & $\begin{array}{l}\text { Time between } \\
\text { infection and lysis of } \\
\text { a cell (lytic cycle) }\end{array}$ \\
\hline$\alpha$ & $\begin{array}{l}1.7 \times \\
10^{-6}\end{array}$ & $\mathrm{ml}$ host $^{-1} \mathrm{~h}^{-1}$ & $\begin{array}{l}\text { Viral adsorption } \\
\text { coefficient }\end{array}$ \\
\hline$S_{1}$ & 0.05 & Dimensionless & $\begin{array}{l}\text { Fraction of collisions } \\
\text { that lead to adsorp- } \\
\text { tion in the absence of } \\
\text { inhibitor }\end{array}$ \\
\hline$S_{2}$ & 0.07 & Dimensionless & $\begin{array}{l}\text { Fraction of adsorp- } \\
\text { tions that lead to } \\
\text { infection }\end{array}$ \\
\hline$\lambda_{V}$ & 0.005 & $\mathrm{~h}^{-1}$ & Viral decay rate \\
\hline$\lambda_{I}$ & 0.005 & $\mathrm{~h}^{-1}$ & Inhibitor decay rate \\
\hline$k$ & $\begin{array}{l}1,2.5 \\
5,10,15 \\
20 \times 10^{-5}\end{array}$ & a.u. & $\begin{array}{l}\text { Inhibitor released per } \\
\text { lytic event }\end{array}$ \\
\hline
\end{tabular}


recovered cultures duplicate, cultures (1 l) of exponentially growing Phaeocystis pouchetii $\left(2.5 \times 10^{5} \mathrm{ml}^{-1}\right)$ were inoculated with $100 \mathrm{ml}$ fresh lysate to a concentration of $1.5 \times 10^{6}$ virus particles $\mathrm{ml}^{-1}$, and the evolution of P. pouchetii, $\mathrm{PpV}$ and bacteria were followed. Uninfected $P$. pouchetii cultures (duplicate) were used as controls. Samples for enumeration of $P$. pouchetii, $\mathrm{PpV}$ and bacteria were taken at regular intervals for ca. $1 \mathrm{yr}$.

Enumeration of algae, virus and bacteria. All analyses were performed with a FACSCalibur flow cytometer (Becton Dickinson) equipped with an aircooled laser providing $15 \mathrm{~mW}$ at $488 \mathrm{~nm}$ and with the standard filter set-up. For enumeration of algal cells, fresh samples were run for 1 to $2 \mathrm{~min}$ at a delivery rate of ca. $30 \mu \mathrm{min}^{-1}$ with the discriminator set on red fluorescence. Viral and bacterial counts were performed on fixed samples $(0,5 \%$ glutaraldehyde, final concentration) diluted from 1:10 to 1:1000 in TE-buffer $(10 \mathrm{mM}$ Tris, $1 \mathrm{mM}$ EDTA, $\mathrm{pH}=8)$ and stained for 10 to $15 \mathrm{~min}$ at $80^{\circ} \mathrm{C}$ with SYBRGreen-I (Molecular Probes) at a final concentration of $10^{-4}$ of the commercial solution (Marie et al. 1999). The samples were analyzed for $1 \mathrm{~min}$ at a flow rate of ca. $30 \mu \mathrm{min}^{-1}$ with the discriminator set on green fluorescence as described in Marie et al. (1999) and Brussaard et al. (2000).
Nutrient analysis. To test if cultures were phosphate-limited, the concentration of soluble reactive phosphorus (SRP) was measured according to Koroleff (1976).

\section{MODEL}

In current models of phytoplankton host-virus interaction, viral production depends on the probability $S_{1}$ that a virus-host collision will lead to adsorption of the virus (Bratbak et al. 1998). We modify this probability by introducing the expression:

$$
\frac{S_{1}}{1+I}
$$

where $I$ is an inhibiting factor given in arbitrary units (a.u.) so that at an a.u. of 1 the probability is reduced to $50 \%$ of its value when no inhibitor is present $\left(S_{1}\right)$. A fixed amount $k$ of inhibitor is assumed to be produced per lytic event, and the inhibitor decay is assumed to be a first-order process with fixed rate constant $\left(\lambda_{I}\right)$. The equations, parameters and initial values used for simulation are given in Table 1. The model was formulated in the Stella programming package running under Windows 95. A Runge-Kutta second-order procedure with time step $1 \mathrm{~h}$ was used.

\section{RESULTS}
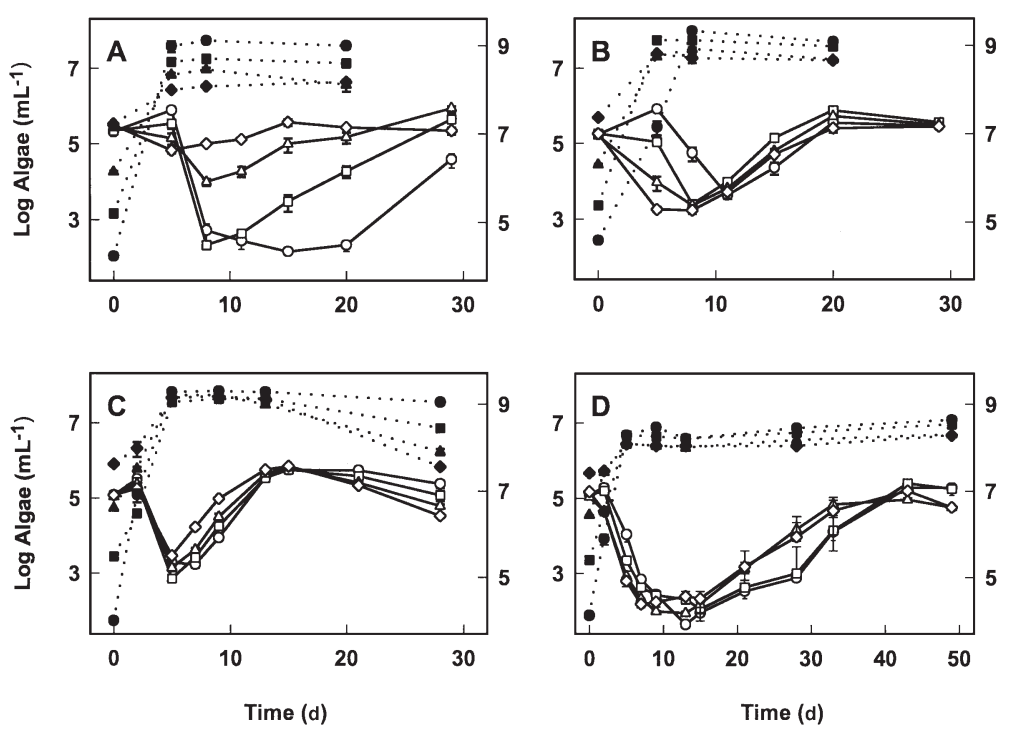

है

Fig. 1. Abundances of algae (O) and viruses ( $\bullet$ ) after addition of the respective virus at Day 0. (A) Emiliania huxleyi and EhV-99B1, (B) Chrysochromulina ericina and CeV-01B, (C) Pyramimonas orientalis and PoV-01B, (D) Phaeocystis pouchetii and $\mathrm{PpV}-01$. Four different initial virus:host ratios were applied, namely $100(\bullet, \diamond), 10(\mathbf{\Delta}, \Delta), 1(\bullet, \square)$ and $0.25(\bullet, \circ)$. Symbols represent average of 3 replicates. Error bars: SE
All infected cultures recovered after viral lysis (Fig. 1). Within a few days after addition of the respective virus, algal abundances decreased and reached minimum densities within 1 to $2 \mathrm{wk}$. In the same period, the viral abundances increased and reached densities of $10^{8}$ to $10^{9} \mathrm{ml}^{-1}$. Following this lysis period, the number of algae grew exponentially until they entered a stationary phase, while the viral populations remained stable compared to the algae. The recovery generally occurred earlier when higher initial virus-to-host ratios were applied. This effect was most obvious in the Emiliania huxleyi cultures (Fig. $1 \mathrm{~A}$; sign test using all values in the regrowth phase until onset of the stationary phase, $p<0.01$ ), but the difference was also significant in the Pyramimonas orientalis and Phaeocystis pouchetii cultures (Fig. $1 \mathrm{C}, \mathrm{D}_{;}$sign test, $\mathrm{p}<0.01$ for both). The 

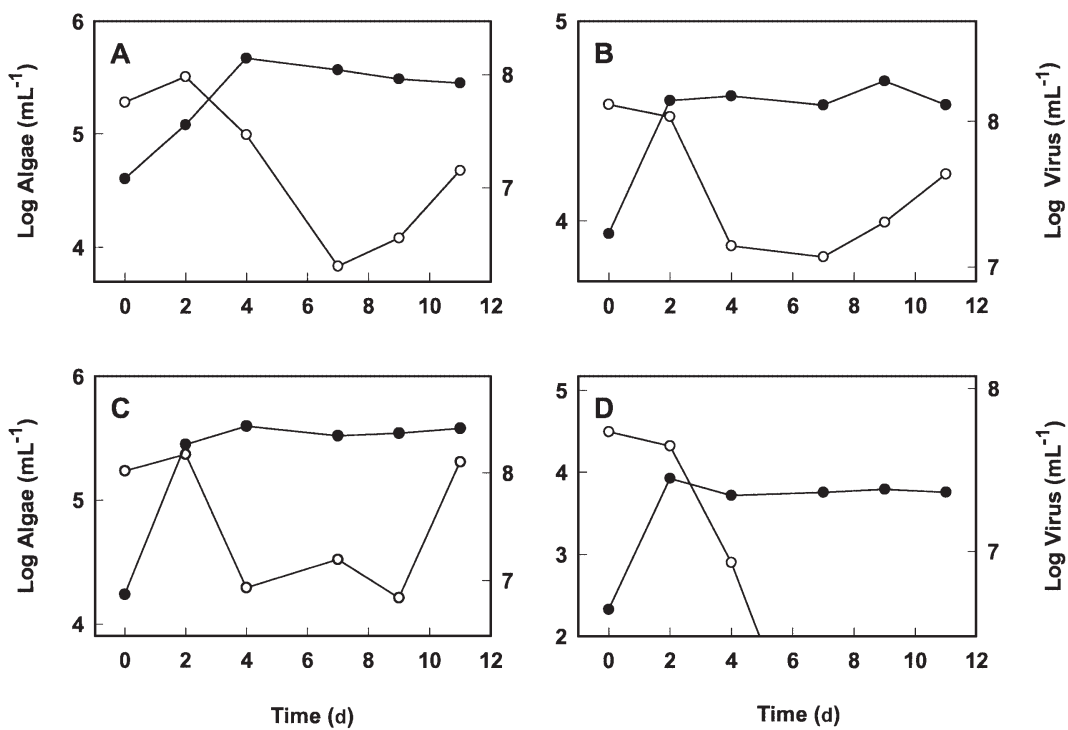

Fig. 2. Abundances of algae (O) and viruses ( $\bullet$ ) after addition of the respective virus from recovered cultures to stock algal cultures. (A) Emiliania huxleyi and EhV-99B1, (B) Chrysochromulina ericina and CeV-01B, (C) Pyramimonas orientalis and PoV-01B, (D) Phaeocystis pouchetii and PpV-01

Chrysochromulina ericina cultures did not lyse at the same time (Fig. 1B) and the onset of the recovery phase cannot therefore be compared for this species.

When viruses from recovered cultures were added to exponentially growing host cultures $>80 \%$ of the host populations were lysed within $1 \mathrm{wk}$, and a concomitant 6- to 30-fold increase in the viral abundance was detected (Fig. 2). In contrast, no abrupt lysis was detected when viruses from fresh lysates were added to recovered cultures (Fig. 3). All cultures showed net growth during the experimental period of $10 \mathrm{~d}$, although the concentration of Chrysochromulina ericina decreased at the end of the period. The viral abundance increased relatively slowly in all cultures except the Pyramimonas orientalis culture, where the viral abundance slowly decreased. Fig. 4 shows the development of algae and viruses in recovered cultures diluted $10 \times$ in fresh medium. Net increases in both algal and viral abundance were detected in all cultures except the $P$. orientalis culture, in which both increased over the first $13 \mathrm{~d}$ and then decreased until the end of the experiment.

Treating the cultures with virus-free lysate prior to addition of the respective virus delayed and/or reduced the extent of cell lysis in the cultures
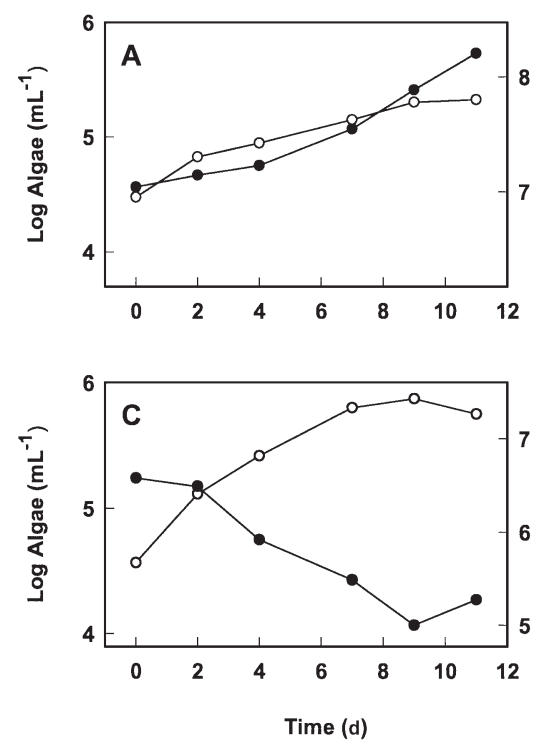

\section{בั}

(Fig. 5). This effect was most pronounced in the Emiliania huxleyi cultures (Fig. 5A), where all treated cultures lysed later than non-treated cultures (sign test using all values except $t=0, \mathrm{p}<0.01$ ). The minimum algal abundances were ca. 100× higher in treated cultures inoculated with $10^{7}$ virus $\mathrm{ml}^{-1}$ compared to the untreated cultures, which represented the other extreme. However, even in the cultures with the lowest level of lysis an $85 \%$ decrease in algal abundance was observed.

For the other 3 species (Fig. 5B-D) delayed lysis was observed in the cultures treated with virus-free lysate when the initial viral concentration was low $\left(10^{5}\right.$ virus $\left.\mathrm{ml}^{-1}\right)$ (sign test using all values except $t=0, \mathrm{p}<0.05$ ). When the initial virus concentration was high $\left(10^{7}\right.$ virus $\left.\mathrm{ml}^{-1}\right)$, however, a significant delay was only observed in the Phaeocystis pouchetii cultures (sign test using all values except $t=0: \mathrm{p}<0.05$ ). We observed no differences in the extent of cell lysis in any of these cultures.

The results from the long-term incubation of infected and non-infected cultures of Phaeocystis pouchetii are shown in Fig. 6. The uninfected control cultures (Fig. 6A) showed exponential growth $\left(\mu=0.68 \mathrm{~d}^{-1}\right)$ until $P$. pouchetii approached $10^{6} \mathrm{ml}^{-1}$. This was fol-
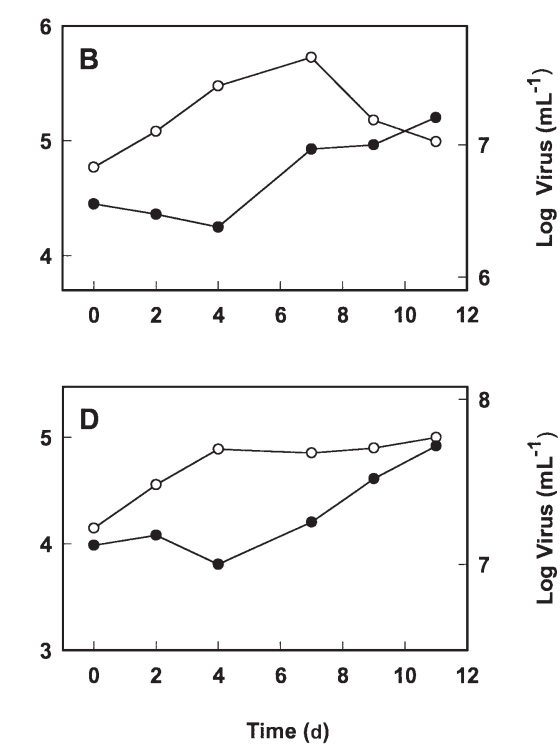

Fig. 3. Abundances of algae (O) and viruses (•) after addition of the respective virus from stock lysates to recovered algal cultures. (A) Emiliania huxleyi and EhV-99B1, (B) Chrysochromulina ericina and CeV-01B, (C) Pyramimonas orientalis and PoV-01B, (D) Phaeocystis pouchetii and PpV-01 

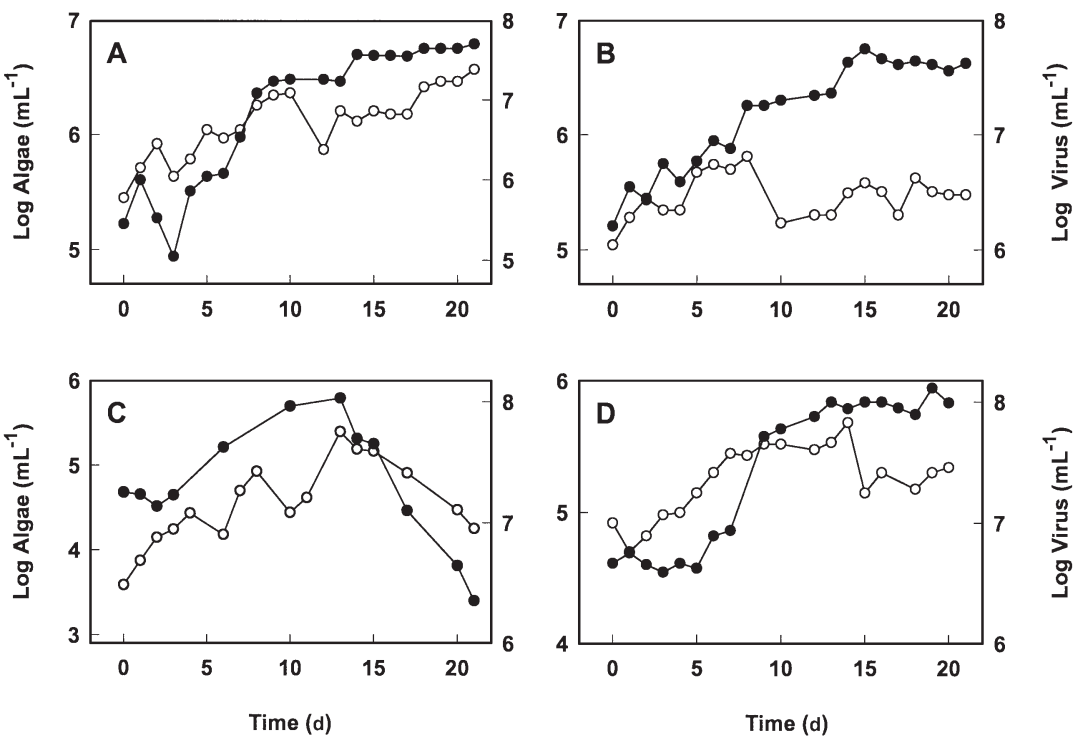

Fig. 4. Abundances of algae $(\mathrm{O})$ and viruses $(\bullet)$ after $10 \times$ dilution of recovered cultures in fresh medium. (A) Emiliania huxleyi and EhV-99B1, (B) Chrysochromulina ericina and CeV-01B01, (C) Pyramimonas orientalis and PoV-01B, (D) Phaeocystis pouchetii and PpV-01

lowed by a stationary phase lasting a few days and then a rapid decline in algal abundance. $P$. pouchetii could not be detected after $42 \mathrm{~d}$. The bacterial abundance was stable at $1.5 \times 10^{6} \mathrm{ml}^{-1}$ until the stationary phase of $P$. pouchetii occurred. At this point, a phase of exponential growth began and continued until the bacterial concentration reached $1.7 \times 10^{8} \mathrm{ml}^{-1}$. Slow bacterial decline followed, which lasted throughout the remaining experimental period. $\mathrm{PpV}$ or any other virus infecting $P$. pouchetii was not observed in the non-infected cultures. Ten $d$ after addition of the virus to the infected cultures the abundance of algae was reduced from $2.5 \times 10^{5}$ to ca. 1000 cells $\mathrm{ml}^{-1}$. At the same time, the viral and bacterial concentrations increased from $1.5 \times 10^{6}$ to $2.1 \times 10^{8} \mathrm{ml}^{-1}$ and from $1.5 \times 10^{6}$ to $1.1 \times 10^{8} \mathrm{ml}^{-1}$, respectively. This pattern was similar to the lysis phase of infected $P$. pouchetii cultures shown in Fig. 1. Fig. 6B shows the abundance of $P$. pouchetii, $\mathrm{PpV}$ and bacteria following initiation of the recovery phase. $P$. pouchetii grew exponentially $\left(\mu=0.33 \mathrm{~d}^{-1}\right)$ until it approached a density of $10^{5} \mathrm{ml}^{-1}$. Then, oscillations in algal abundance with large amplitudes occurred over the next 100 to $150 \mathrm{~d}$, before it
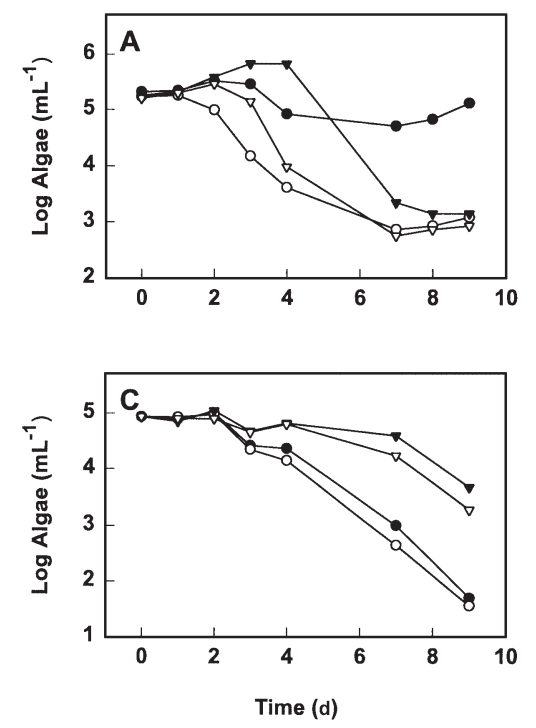

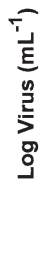

stabilized at $10^{4}$ to $10^{5} \mathrm{ml}^{-1}$ for the remaining experimental period. The maximum and minimum concentrations of algae were ca. $10^{5}$ and $10^{3} \mathrm{ml}^{-1}$, respectively. In the same period, $\mathrm{PpV}$ and bacteria underwent minor oscillations, compared to $P$. pouchetii.

Soluble reactive phosphorous (SRP) was measured in both infected and non-infected cultures $52 \mathrm{~d}$ after the beginning of the experiment. In the control cultures, the SRP concentrations were below the detection limit of approximately $0.02 \mu \mathrm{M}$, while the infected cultures had SRP concentrations of $6.5 \pm 0.5 \mu \mathrm{M}$.

The parameters and equations in Table 1 were used as input to the simulaton model. The effect of the amount of inhibitor produced $(k)$ on the stability properties of the system is illustrated in Fig. 7. For the model conditions defined: $k=1 \times 10^{-5}$ a.u. per lytic event gives oscillations that increase in amplitude for the $300 \mathrm{~d}$ period simulated; $k=2.5 \times 10^{-5}$ a.u. gives stable oscillations; $k=5,10$ and $15 \times 10^{-5}$ a.u. give increasingly damped oscillations towards steady states; for $k=20 \times 10^{-5}$ a.u. the inhibitor production is so large that viruses never manage to reduce the algal
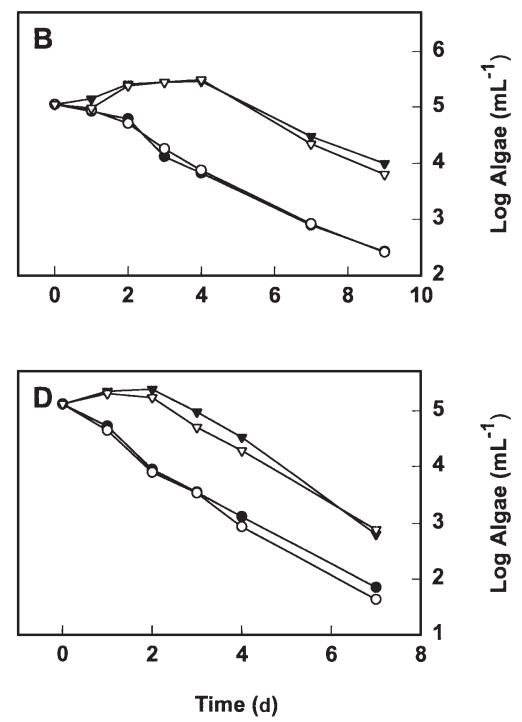

Fig. 5. Algal abundances in cultures with $(\bullet, \nabla)$ or without $(0, \nabla)$ treatment for 10 $\mathrm{min}$ with $10 \% \mathrm{v} / \mathrm{v}$ virus-free lysate before addition of the respective virus. (A) Emiliania huxleyi and EhV-99B1, (B) Chrysochromulina ericina and CeV01B, (C) Pyramimonas orientalis and PoV-01B, (D) Phaeocystis pouchetii and $\mathrm{PpV}$-01. Initial viral concentrations $10^{7} \mathrm{ml}^{-1}(\bullet, 0)$ and $10^{5} \mathrm{ml}^{-1}(\mathbf{v}, \nabla)$ were applied. Symbols represent average of duplicate cultures 


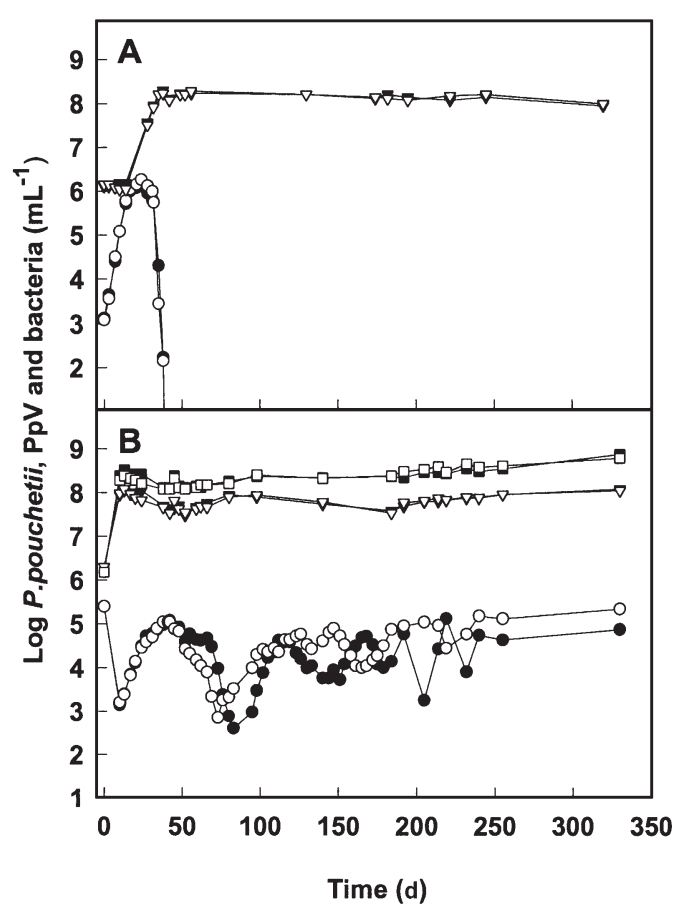

Fig. 6. Abundances of Phaeocystis pouchetii $(\bullet, 0)$, bacteria $(\mathbf{v}, \nabla)$ and PpV-01 ( $\square, \square)$ in (A) uninfected and (B) recovered cultures of $P$. pouchetii. Open and closed symbols represent duplicate cultures. PpV was never observed in uninfected cultures

population. Host, virus, and inhibitor concentrations then continue to grow until halted by some other limiting condition, not included in this model (Fig. 7).

\section{DISCUSSION}

\section{Effect of viral inoculum on lysis and recovery}

A striking pattern in our results is that addition of more virus generally resulted in delayed host lysis and in faster host recovery (Fig. 1). This effect was most pronounced in the Emiliania huxleyi cultures, but it was also observed in the Pyramimonas orientalis and the Phaeocystis pouchetii cultures. In the Chrysochromulina ericina cultures the lysis period was considerably longer in the cultures that were inoculated with less virus. For the other 3 species, the time required for mass lysis was independent of viral inoculum, or the difference was less than the sampling intervals.

\section{Viral infectivity, algal resistance and persistency of infection}

All microalgal viruses isolated so far are described as lytic with no evidence of latent infections (Mayer \&
Taylor 1979, van Etten \& Meints 1999, Sandaa et al. 2001, Castberg et al. 2002). Thus, we focused on explanations for the recovery that are in accordance with strictly lytic host-virus systems, although the possibility of latent infections cannot be completely excluded.

A current mathematical model for lytic algal hostvirus interactions suggests rapid algal extinction followed by slow viral decay (Bratbak et al. 1998). This model assumes that the virus and its host are phenotypically stable in terms of decay rates, burst sizes, diffusion coefficients, absorption coefficients, latent periods, infectivity, and growth rates. A change in 1 or more of these parameters may alter the kinetics of the hostvirus interaction, and recovery of the host algal population is then 1 possible outcome. The observations made in this study - that viruses from recovered algal cultures and viruses from the original stocks had the same

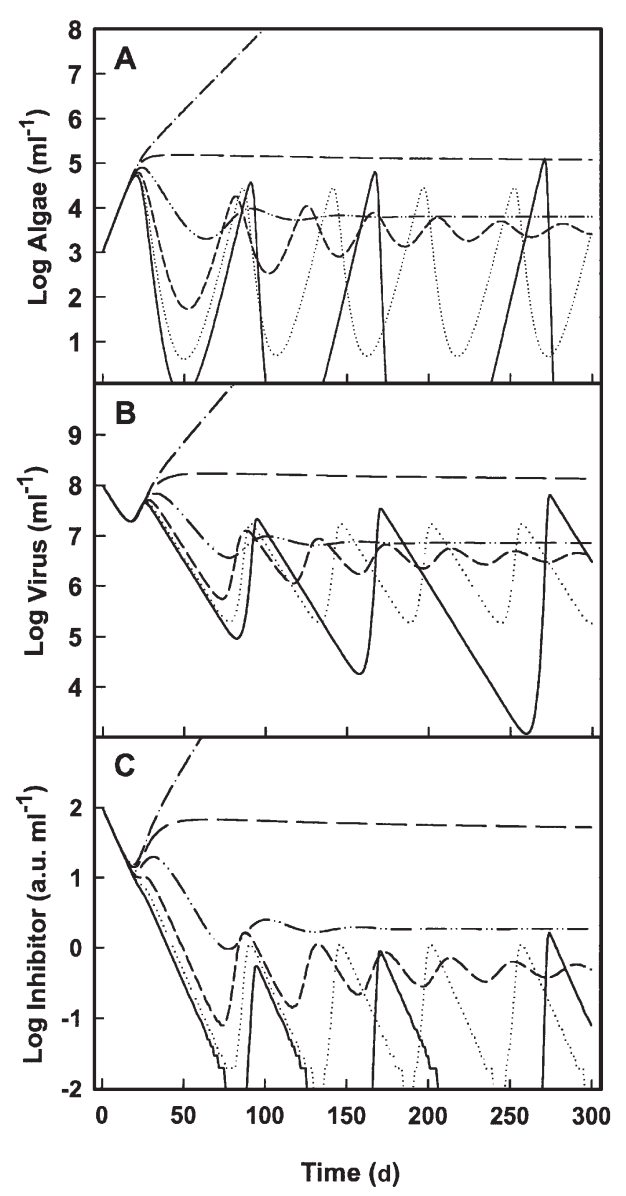

Fig. 7. Simulation of (A) Phaeocystis pouchetii, (B) PpV, and $(C)$ inhibitor concentration $(k)$ for the first $300 \mathrm{~d}$ after initiation of algal recovery following viral lysis. Simulation is given for 6 different values of $k\left(-: 1 \times 10^{-5}, \ldots . .: 2.5 \times 10^{-5},---: 5 \times\right.$ $10^{-5},-\cdot-: 10 \times 10^{-5},--: 15 \times 10^{-5},-\cdot-: 20 \times 10^{-5}$ arbitrary units [a.u.]) 
effect when added to fresh algal cultures - indicate that there is no phenotypic change in the viruses (Fig. 2). The alternative hypothesis is that the hosts are phenotypically plastic and develop some kind of resistance to viral infection, which allows the cultures to recover after the initial virus attack. Fig. 3 suggests that this was indeed the case, as re-inoculation of cultures in the recovery phase with fresh virus did not result in rapid lysis with concomitant viral increase. Instead, the typical pattern was slow viral accumulation simultaneously with algal growth, indicating that the infection rate (and the resulting lysis rate) was lower than the growth rate. In the Pyramimonas orientalis culture, the viral abundance decreased over the first $9 \mathrm{~d}$ before it increased. This does not necessarily mean that no viral production occurred, but rather that the sum of decay and adsorption rate was higher than the production rate.

When recovered cultures were diluted in fresh medium the abundance of both algae and viruses increased in all cultures during the incubation period of 3 wk (Fig. 4). This shows that algal hosts and their infective viruses are able to coexist at high abundances in the same culture, and that they can grow simultaneously. This occurred in all cultures, with the exception of the Pyramimonas orientalis culture in which PoV declined after an increase in the first $2 \mathrm{wk}$. This may indicate that PoV particles are more unstable than the other virus particles examined in this study, or that a lower susceptibility of $P$. orientalis to viral infection causes a net decrease in viral production.

\section{Inhibiting effect of filtered lysate}

Mass lysis was delayed and also, in some cases (e.g. Emiliania huxleyi cultures), the extent of cell lysis was reduced when the algal cultures were treated with virus-free lysate for $10 \mathrm{~min}$ before addition of the respective virus. This effect may be explained by a mechanism similar to that allowing survival of phageinfected Shigella dysenteriae (Li et al. 1961). Clones of S. dysenteriae carrying phage T7 in a pseudolysogenic relationship were shown to change phenotype from $\mathrm{Lac}^{-} \mathrm{Mann}^{-}$to $\mathrm{Lac}^{+} \mathrm{Mann}^{+}$, and this change was attributed to an alteration of surface structures by phageassociated endolysin. Li et al. (1961) suggested that endolysin also removed phage receptors from the cell surface that rendered the remaining host cells resistant to infection; thus, a long-term association between host and parasite could be established without involving true lysogeny. In terms of our results, endolysin may act as a non-specific inhibitor to viral infection, and more specific inhibitors may facilitate recovery and stable coexistence. Infected cells produce an excess of viral molecules during viral reproduction, and these are released when the cells lyse (Joset \& GuespinMichel 1993). Thus, viral host recognition molecules may be released during cell lysis and compete with complete virus particles for receptor sites on the host cell surface, thereby reducing the fraction of collisions that results in adsorption.

Both specific and non-specific inhibitors may act as cues, giving information about viral activity. The resulting effect would be an inverse co-variation between viral absorption rate and viral abundance, fitting with the reported undetectable absorption of $\mathrm{MpV}$ in recovered Micromonas pusilla cultures (Suttle 2000). As more cells lyse the concentration of inhibitors would increase, the infection rate would decrease and algal extinction would be avoided. Net algal growth occurs when the infection rate becomes slower than the host's specific growth rate, and viral abundance decreases when the viral decay rate exceeds production. The inhibitors may be destroyed (e.g. by bacteria or chemically) and when the decay rate of inhibitors exceeds the production rate (proportional to viral production rate and algal lysis rate), the specific absorption rate would again begin to rise. Inhibitors would thus be a stabilizing factor that makes coexistence of algae and viruses more likely.

A stable coexistence was established for all hostvirus systems but the effect of adding filtered lysate was pronounced only in the Emiliania huxleyi cultures. This suggests that mechanisms other than filterable inhibitors may have been involved. One such mechanism, which would be removed by filtration, could be defective interfering particles which are mutant viruses with partially deleted genomes that require a coinfection with the wild-type virus to be able to replicate within host cells (Roux et al. 1991, Frank 2002). Defective interfering particles would inhibit the production of normal wild-type viruses, and the rate of lytic infections would decrease over time.

If cells are susceptible to viral infection only during certain life stages, this may contribute to a stabilization of host-virus dynamics (Lenski 1988a). Thyrhaug et al. (2002) showed that the viral production in Pyramimonas orientalis cultures infected with PoV depend on the timing of infection in relation to the host's cell. According to Lenski (1988a), this constraint may have contributed to a stable host-virus interaction in recovered cultures. However, modelling indicates that this constraint is not enough to stabilize the host-virus interaction in systems characterized by low growth rate, high burst size and long infection cycles, and this mechanism is thus probably of less significance in the systems studied here (modelling results not shown). Moreover, no such cell-cycle-dependent infection was found for Phaeocystis pouchetii infected with PpV (Thyrhaug et al. 2002), and the mechanism appears thus not to apply to all host-virus systems. 


\section{Ecological implications}

The possible effect of such a feedback mechanism is demonstrated in the population dynamics in infected and non-infected batch cultures of Phaeocystis pouchetii. Prolonged (at least $1 \mathrm{yr}$ ) coexistence of $P$. pouchetii and its virus $\mathrm{PpV}$ occurred in the infected cultures while the algae died off and disappeared within a few weeks in the cultures without PpV. Feedback may prevent the algae from extinction, while regeneration of nutrients caused by algal lysis prevents nutrient depletion. The modified model presented here illustrates that phenotypic plasticity of the host's susceptibility to infection may be important as a stabilizing factor in host-virus interactions. The inhibitor inserted in the model represents all kinds of decayable mechanisms that reduce the frequency of collisions which lead to adsorption. Thus, endolysin and other inhibitors that may be released when cells lyse potentially play a significant role in avoiding extinction of infected phytoplankton populations.

It is also noteworthy that the microbial community (Phaeocystis pouchetii, bacteria and bacteriophages) in uninfected cultures is not capable of efficient enough recycling to support the alga with nutrients: viral lysis of the alga by $\mathrm{PpV}$ is also required. Being infected may thus be an advantage for phytoplankton populations, as viral lysis yields nutrients that are available for all osmotrophs. The phytoplankton population experiences a continuous input of regenerated nutrients instead of being met with depletion.

Although the inhibiting effect of filtered lysate was significant in most of the algal host-virus systems, the effect in the Emiliania huxleyi cultures was much more pronounced than in the other host-virus systems. This may be attributed to a higher release of inhibiting factors when E. huxleyi cells lyse and/or to greater stability of these factors in these cultures. The stability of viral particles may vary between the cultures: both the initial recovery experiment and the dilution experiment suggest that PoV particles are more unstable than the other viruses examined, or that the decrease in susceptibility to infection was more efficient in Pyramimonas orientalis cultures. The degree of inhibiting effects, stability of these effects and stability of the viruses are all factors that may contribute to the regulation of host-virus dynamics in natural waters.

Parasites should evolve reduced virulence to their hosts because the most successful parasites are those that do the least harm to their hosts (Lenski \& May 1994). Another hypothesis is that greater virulence is favoured when the host density is high, while reduced virulence is favoured when the host density is low (Ewald 1983, Lenski 1988b). The feedback mechanism in the algal host-virus systems presented here resem- bles the latter hypothesis, although it implies a mechanism corresponding to phenotypic plasticity in host susceptibility to infection rather than genetic evolution. When the host concentration is low, due to viral lysis, the concentration of inhibitor will be high and the probability of successful infections will be low (corresponding to low virulence). Likewise, when the host concentration is high, the concentration of inhibitor will be low and the probability of successful infections will be high (corresponding to high virulence). Over short time-scales, such as the duration of an algal bloom, this mechanism of regulating the level of infection is rapid and powerful, and may play an ecologically significant role.

Several mechanisms have been proposed to explain how microbial predators and parasites can coexists with their preys and hosts. These include interactions among predators, predators under biological control, genetic feedback, refuge, switching, density dependence and replication to compensate for killing (Alexander 1981). Conceptually close to the mechanism proposed here, are mechanisms reducing the strength of the predatorprey interaction when predation is severe (Hessen \& VanDonk 1993). Until now, none of these have been shown to be important in regulating algal host-virus interactions, but the feedback response described in the present study may be interpreted as a special case of replication to compensate for killing. The dynamic feedback response allows coexistence of algae and viruses at both high and low densities and may therefore explain why viruses infecting both bloom-forming (Milligan \& Cosper 1994, Jacobsen et al. 1996, Nagasaki \& Yamaguchi 1997) and non-bloom-forming phytoplankton species (Mayer \& Taylor 1979, Sandaa et al. 2001) can be readily found in natural waters. Moreover, speculations about whether parasites can be of benefit to their hosts have been raised (Palmieri 1982), and our results show that an endemic viral infection in a phytoplankton population may indeed be an ecological advantage to the host.

Acknowlegements. We thank Rune Kleppe for keeping cultures forever, and 3 anonymous reviewers for constructive comments. This work was supported by grants from The Research Council of Norway (project no. 121425/420) and the EC through contract EVK3-CT-2001-00049 'DANLIM'. The FACSCalibur flow cytometer was in part funded by a grant from The Knut and Alice Wallenberg Foundation to the Virtue program.

\section{LITERATURE CITED}

Alexander M (1981) Why microbial predators and parasites do not eliminate their prey and hosts. Annu Rev Microbiol 35:113-133

Bratbak G, Egge JK, Heldal M (1993) Viral mortality of the 
marine alga Emiliania huxleyi (Haptophyceae) and termination of algal blooms. Mar Ecol Prog Ser 93:39-48

Bratbak G, Levasseur M, Michaud S, Cantin G, Fernández E, Heimdal BR, Heldal M (1995) Viral activity in relation to Emiliania huxleyi blooms: a mechanism of DMSP release? Mar Ecol Prog Ser 128:133-142

Bratbak G, Jacobsen A, Heldal M, Nagasaki K, Thingstad TF (1998) Virus production in Phaeocystis pouchetii and its relation to host cell growth and nutrition. Aquat Microb Ecol 16:1-9

Brussaard CPD, Marie D, Bratbak G (2000) Flow cytometric detection of viruses. J Virol Methods 85:175-182

Castberg T, Larsen A, Sandaa RA, Brussaard CPD and 5 others (2001) Microbial population dynamics and diversity during a bloom of the marine coccolithophorid Emiliania huxleyi (Haptophyta). Mar Ecol Prog Ser 221:39-46

Castberg T, Thyrhaug R, Larsen A, Sandaa RA, Heldal M, Van Etten JL, Bratbak G (2002) Isolation and characterization of a virus that infects Emiliania huxleyi (Haptophyceae). J Phycol 38:767-774

Ewald PW (1983) Host-parasite relations, vectors and the evolution of disease severity. Annu Rev Ecol Syst 14: 465-485

Frank SA (2002) Within-host spatial dynamics of viruses and defective interfering particles. J Theor Biol 206:279-290

Fuhrman JA (1999) Marine viruses and their biogeochemical and ecological effects. Nature 399:541-548

Guillard RRL (1975) Culture of phytoplankton for feeding marine invertebrates. In: Smith WL, Chanley MH (eds) Culture of marine invertebrate animals. Plenum Press, New York, p 29-60

Hessen DO, VanDonk EH (1993) Morphological changes in Scenedesmus induced by substances released from Daphnia. Arch Hydrobiol 127:129-140

Jacobsen A, Bratbak G, Heldal M (1996) Isolation and characterization of a virus infecting Phaeocystis pouchetii (Prymnesiophyceae). J Phycol 32:923-927

Joset F, Guespin-Michel J (1993) Prokaryotic genetics. Blackwell Science, Oxford, p 79-131

Koroleff F (1976) Determination of phosphorus. In: Grasshoff K (ed) Methods in seawater analysis. Verlag Chemie, Weinheim, p 117-125

Larsen A, Castberg T, Sandaa RA, Brussaard CPD and 6 others (2001) Population dynamics and diversity of phytoplankton, bacteria and virus in a seawater enclosure. Mar Ecol Prog Ser 221:47-57

Lenski RE (1984) Coevolution of bacteria and phage: are there endless cycles of bacterial defenses and phage counterdefenses? J Theor Biol 108:319-325

Lenski RE (1988a) Dynamics of interactions between bacteria and virulent bacteriophage. Adv Microb Ecol 10:1-44

Lenski RE (1988b) Evolution of plague virulence. Nature 334: $473-474$

Lenski RE, Levin BR (1985) Constraints on the coevolution of bacteria and virulent phage: a model, some experiments, and predictions for natural communities. Am Nat 125: $585-602$

Editorial responsibility: Otto Kinne (Editor),

Oldendorf/Luhe, Germany
Lenski RE, May RM (1994) The evolution of virulence in parasites and pathogens - reconciliation between 2 competing hypotheses. J Theor Biol 169:253-265

Li K, Barksdale L, Garmise L (1961) Phenotypic alterations associatied with the bacteriophage carrier state of Shigella dysenteriae. J Gen Microbiol 24:355-367

Marie D, Brussaard CPD, Thyrhaug R, Bratbak G, Vaulot D (1999) Enumeration of marine viruses in culture and natural samples by flow cytometry. Appl Environ Microbiol 65:45-52

Mayer JA, Taylor FJR (1979) A virus which lyses the marine nanoflagellate Micromonas pusilla. Nature 281:299-301

Milligan KLD, Cosper EM (1994) Isolation of virus capable of lysing the brown tide microalga, Aureococcus anophagefferens. Science 266:805-807

Nagasaki K, Yamaguchi M (1997) Isolation of a virus infectious to the harmful bloom causing microalga Heterosigma akashiwo (Raphidophyceae). Aquat Microb Ecol 13: $135-140$

Nagasaki K, Imai I, Itakura S, Ando M, Ishida Y (1995) Viral infection in Heterosigma akashiwo (Raphidophyceae): a possible termination mechanism of the noxious red tide. In: Lassus P, Arzul G, Erard E, Gentien P, Marcaillou C (eds) Harmful marine algal blooms. Intercept, Paris, p 639-644

Palmieri JR (1982) Be fair to parasites. Nature 298:220

Roux L, Simon AE, Holland JJ (1991) Effects of defective interfering viruses on viral replication and pathogenesis in vitro and in vivo. Adv Virus Res 40:181-211

Sandaa RA, Heldal M, Castberg T, Thyrhaug R, Bratbak G (2001) Isolation and characterization of two viruses with large genome size infecting Chrysochromulina ericina (Prymnesiophyceae) and Pyramimonas orientalis (Prasinophyceae). Virology 290:272-280

Suttle CA (2000) Ecological, evolutionary, and geochemical consequences of viral infection of cyanobacteria and eukaryotic algae. In: Hurst CJ (ed) Viral ecology. Academic Press, San Diego, p 247-296

Tarutani K, Nagasaki K, Yamaguchi M (2000) Viral impacts on total abundance and clonal composition of the harmful bloom-forming phytoplankton Heterosigma akashiwo. Appl Environ Microbiol 66:4916-4920

Thyrhaug R, Larsen A, Brussaard CPD, Bratbak G (2002) Cell cycle dependent virus production in marine phytoplankton. J Phycol 38:338-343

van Etten JL, Meints RH (1999) Giant viruses infecting algae. Annu Rev Microbiol 53:447-494

Waters RE, Chan AT (1982) Micromonas pusilla virus: the growth cycle and associated physiological events within the host cells; host range mutation. J Gen Virol 63: 199-206

Wommack KE, Colwell RR (2000) Virioplankton: viruses in aquatic ecosystems. Microbiol Mol Biol Rev 64:69-114

Zingone A, Sarno D, Forlani G (1999) Seasonal dynamics in the abundance of Micromonas pusilla (Prasinophyceae) and its viruses in the Gulf of Naples (Mediterranean Sea). J Plankton Res 21:2143-2159

Submitted: August 19, 2002; Accepted: March 11, 2003

Proofs received from author(s): May 9, 2003 